\title{
Editorial
}

\section{Who's to blame?}

Peter G. Duncan MD FRCPC

Whenever something can go wrong it will, and someone must be at fault! So assumes the traditional hospital morbidity and mortality committee and other peer review bodies examining medical practice. However, recent developments in anaesthesia outcome analysis must call such simplistic conclusions to question.

The medical theory of disease frequency suggests causation is usually anything but straightforward. ${ }^{1}$ A given outcome is usually made up of a collection of factors (component causes) that, when grouped together, can generate the event in question (sufficient cause for the outcome). A component cause that is absolutely required (necessary cause) may be identified, but by itself is not capable of the disease expression. Thus stepping upon a rusty nail may be a necessary cause of the development of a case of tetanus, but without medical inattention and absent immunity as other component causes, sufficient cause will not be generated, and the disease will not occur.

Anaesthetic problems are similarly complex. Technological, pharmaceutical, and professional advances in recent years have reduced the frequency of adverse outcome from anaesthesia considerably, although allocation of credit remains speculative. ${ }^{2}$ Seldom are cases of post-anaesthetic morbidity or mortality a simple error on behalf of the anaesthetist: in the closed claims study of the United States peer review suggested over $50 \%$ of cases demonstrated a standard of anaesthetic practice equal or greater than that in the community, ${ }^{3}$ while the New South Wales Mortality review suggests only $12.4 \%$ of post-anaesthesia mortality has an anaesthetic component. ${ }^{4}$ Gaba and colleagues have discussed the multifactorial aetiology of anaesthetic disasters, and have pioneered the application of simulators to study the complex interaction of factors necessary for the "anaesthetic disaster" 5 to occur.

This issue of the journal features a further major contribution to the study of anaesthetic complications. Eagle et al. from Calgary report a single case of fatal aspiration of gastric contents by an elderly patient, and analyse the errors discovered in his case. ${ }^{6}$ What makes this

Department of Anaesthesia, University of Saskatchewan, Saskatoon, Saskatchewan S7N 0XO.

Accepted for publication 19th September 1991. contribution noteworthy is that the case resembles those found in any North American hospital, as do the contributing "causes." However, rather than focusing solely upon the attending anaesthetist and the "active" errors in his performance, the authors have extended the analysis to include "latent" problems in the history of the case. In parallel with traditional causation theory, the anaesthetic administered was a "necessary" event for the unfortunate outcome, but by itself would not have been sufficient without the other "component causes" of the disaster. While sceptics may suggest such analysis simply rationalizes the physician's errors, it is a major step forward in the understanding of why anaesthetic tragedy still occurs.

That latent factors affecting anaesthetic safety exist should not be a surprise, for they have been identified frequently. For example, structural analysis of anaesthetic machines in Manitoba, ${ }^{7}$ Saskatchewan, ${ }^{8}$ and the USA $^{9}$ have shown that refurbishing and maintenance is often below standards, while a review of dantrolene sodium availability to Eastern Ontario hospitals showed $13 \%$ did not have availability of a sufficient supply. ${ }^{10}$ An extensive analysis of the anaesthetic workplace and the human factors impacting upon operating room performance has recently been published; ${ }^{11}$ there is much to learn, but elements such as fatigue, ambient noise, lighting, and the stress of busy lists can be contributing causes to disasters. Dr. Eagle presents further problems in his analysis, including the failure of computer-based communication from the ward, and the oft-seen but seldom criticized practice of surgical double-booking. What other latent factors exist in other hospitals remain to be uncovered, but this case report should heighten sensitivity to the problem.

Can these tragedies be prevented? A thorough, scheduled review by the anaesthetists and staff of the operating suite of the structure and process used in patient handling will regularly reveal deficiencies; the American Society of Anesthesiologists has published an excellent monograph as a basis of such surveys. ${ }^{12}$ It is imperative that any factor detracting from "process," once identified, be addressed in an appropriate manner. This is the basis of "risk management," heavily subscribed by administrators, and intended to reduce future unplanned financial loss. As an example, the message you didn't receive today may have been inconsequential but, as shown by Dr. Eagle, may be important to future patients. The continuous improvement 
in quality can only occur if every departmental member assists in the process of problem identification.

Most importantly, anaesthetists must be willing to become involved in activities directed to the quality of their practice and their hospital administration. Anaesthetists represent the fourth largest group of medical specialists in the Royal College of Canada, yet they are too often represented at administrative forums such as the Medical Advisory Committee by others. The permanent head of the Operating Room Committee in 19 of 24 teaching hospitals in Canada is the head of the Department of Surgery; anaesthetists, in spite of spending their entire working life there, direct the administration in only two hospitals. It is not necessary to control such committees, but effective modification of issues of anaesthesia concern is impossible without active involvement. For example, administrative naivity could possibly have contributed to Dr. Eagle's case in two ways: the common disdain of surgeons for telephones in the operating room makes direct inquiry of the ward difficult for the anaesthetist, while allowing the practice of surgeon-directed rearrangement of lists and double-booking precludes anaesthetist review of all patients. The challenge of traditional forms of administration and practice takes courage and vision; when changes are perceived to affect the right of physicians to regulate their practice or make money ${ }^{13}$ the rebuttals may become malicious. Nevertheless, change is inevitable if the "latent pathogens" in our environment are to be eradicated.

In spite of variable opposition, anesthetists in Canada and the USA have witnessed the financial and professional benefits of conscientious attention to quality in our practice. ${ }^{14}$ If further reason to act is necessary, the recent conviction of two anaesthetists in Britain of manslaughter after misadventures should reinforce the responsibility each physician bears for his or her actions. ${ }^{15}$ Undoubtedly use of the objective form of analysis described by Dr. Eagle will reduce the chance of ever generating "sufficient cause" for an anaesthetic tragedy. It now appears that how an operating room conducts its business can be an anaesthetic hazard, and its critical assessment must form a mandatory part of our quality assurance requirement.

\section{A qui la faute ?}

Tel un Confucius pessimiste, Murphy nous assure de l'inévitabilité de malheur techniquement possible et de la non moins certaine responsabilité de celui qu'on devra blâmer. Cette doctrine s'inscrit en filigrane des travaux des comités d'étude de morbidité et mortalité hospitalières et autres conciles de pairs évaluant la qualité de la pratique médicale. Il faudra toutefois réévaluer l'à propos de ce manichéisme à la lumière des nouvelles tendances issues de l'analyse des résultats anesthésiques.

L'épidémiologie peut rarement établir une relation causale directe entre facteur et maladie. ${ }^{1}$ Un dénouement quelconque est souvent le résultat d'une constellation de facteurs se liguant circonstantiellement. On peut souvent identifier un facteur comme représentant une condition nécessaire mais non suffisante à l'expression d'une maladie.

Les incidents anesthésiques sont tout aussi complexes. Ces dernières années, l'amélioration des techniques, des médicaments et de la formation professionnelle en a réduit le nombre de façon substantielle, même si on ne s'entend pas sur la contribution relative de chacun de ces facteurs. ${ }^{2}$ Les accidents anesthésiques résultent rarement d'une simple erreur de l'anesthésiste: l'étude par des pairs des réclamations réglées, aux Etats-Unis, révèle que dans plus de $50 \%$ des cas, la pratique de l'anesthésiste en cause était au moins égale au standard des collègues de sa communaute. ${ }^{3}$ Au Pays de Galles, une étude des décès survenus après une anesthésie n'a pu identifier une contribution de cette dernière que dans $12,4 \%$ des cas. ${ }^{4}$ Gaba et ses collègues se sont déjà penché sur l'étiologie multifactorielle des accidents anesthésiques et ont les premiers employé des simulateurs dans l'étude de l'interaction complexe des facteurs menant à une «catastrophe anesthésique $» .^{5}$

On trouvera plus loin dans ce numéro du Journal une contribution majeure au chapitre de l'étude des complications anesthésiques. Eagle et ses collègues de Calgary nous racontent un cas d'aspiration du contenu stomacal ayant entraîné le décès d'un patient âgé et analysent pour nous les facteurs qui $\mathrm{y}$ ont contribué. ${ }^{6} \mathrm{Au}$ delà des «causes » de cet accident, banal somme toute, qui aurait pu survenir n'importe où en Amérique du Nord, au lieu de s'en tenir dans leur analyse aux erreurs par commission de l'anesthésiste, les auteurs s'attardent aux omissions qui jonchent l'histoire du cas, ces facteurs latents pavant la voie à une catastrophe. Dans le schème d'une relation de causalité, l'anesthésie représentait une condition nécessaire mais non suffisante à la survenue de l'accident qui ne serait pas arrivé sans la contribution de «conditions associées». Il n'est pas question ici de rationaliser l'erreur médicale mais plutôt de mieux comprendre pourquoi surviennent encore des drames en anesthésie.

L'existence de conditions associées minant la sûreté de l'anesthésie n'est pas une nouvelle puisqu'elle a souvent été décriée. Ainsi, l'analyse structurelle du parc de machines anesthésiques au Manitoba, ${ }^{7}$ en Saskatchewan ${ }^{8}$ 
et aux Etats-Unis ${ }^{9}$ a démontré que les réparations et l'entretien de ces appareils sont souvent déficients. Par ailleurs, 13\% des hôpitaux de l'est de l'Ontario avaient une quantité de dantrolène insuffisante pour pallier à une crise $\mathrm{d}^{\prime}$ hyperthermie maligne. ${ }^{10}$ On a récemment publié une analyse ergonomique du poste de l'anesthésiste et des facteurs humains prévalant en salle d'opération qui diminuent la performance; ${ }^{11}$ on y note entre autres que la fatigue, le bruit ambiant, l'éclairage et le stress associé à une liste opératoire chargée peuvent contribuer aux désastres qui surviennent encore. Dans son analyse, le $\mathrm{Dr}$ Eagle note au passage d'autres facteurs tels l'absence de système informatisé de communication entre salle d'opération et unité de soins de même que l'incapacité pour les chirurgiens d'être en même temps dans deux salles à la fois même si certains d'entre eux persistent à ce petit jeu. Il existe certainement d'autres facteurs contribuant aux accidents mais l'article que vous pourrez lire soulève le voile sur certains d'entre eux et devrait faire de nous des praticiens plus alertes et suspicieux.

Peut-on prévenir les catastrophes anesthésiques? La révision régulière des éléments structurels et des procédures employées dans le soin des patients va souvent révéler des déficiences et une monographie récente publiée par l'American Society of Anesthesiologists peut servir de guide pour mener à bien cet exercice. ${ }^{12}$ Toute déficience identifiée doit alors être corrigée. C'est là la base de la "gestion du risque » chère à nos administrateurs, dont le but est de minimiser toute perte financière imprévue. A titre d'exemple, le message que vous n'avez pas reçu aujourd'hui ne portait peut-être pas à conséquence mais, comme le démontre le Dr Eagle, il aurait pu être important pour un autre patient. La recherche de la qualité totale n'est possible qu'avec la participation de tous les membres du département à l'identification des problemes.

Il importe encore plus, que les anesthésistes prennent une part active aux activités influant la qualité de leur pratique et l'administration de leur hôpital. Au sein du Collège Royal du Canada, les anesthésistes forment le quatrième groupe en importance chez les spécialistes, toutefois, au sein de leur propre institution, à l'exécutif du Conseil des Médecins, ils sont souvent représentés par d'autres. Ainsi, le responsable statutaire du Comité du bloc opératoire est le chef du départment de chirurgie dans 19 des $24 \mathrm{CHU}$ canadiens que nous avons analysés; les anesthésistes, même s'il passent toute leur vie professionnelle au bloc, n'en dirigent l'administration que dans deux institutions. Le contrôle de ces comités n'est pas obligatoire, mais les anesthésistes n'arriveront jamais à mettre leurs préoccupations à l'agenda sans une participation active. L'absence d'implication administrative a peut-être contribué de deux façons à l'accident raconté par le Dr Eagle; l'objection des chirurgiens à la présence de téléphone en salle d'opération rend difficile les communications entre l'anesthésiste et l'unité de soins tandis que leur pratique consistant à modifier à la demière minute la liste opératoire et à travailler dans deux salles à la fois empêche l'anesthésiste de voir tous les patients à l'avance. Cela prend du courage et de la motivation pour changer les pratiques administratives établies, d'ailleurs, quand ces changements peuvent sembler modifier le droit de gérance d'un médecin sur sa pratique et sur ses revenus, ${ }^{13}$ ils risquent de rencontrer une forte opposition. Mais si nous devons éradiquer les «pathogènes latents » de notre environnement de travail, ces changements sont incontournables.

Malgré les difficultés rencontrées, les anesthésistes canadiens et américains ont su financièrement et professionnellement tirer avantage d'une plus grande attention portée à la qualité de leur pratique. ${ }^{14} \mathrm{Si}$ ce n'était suffisant, le récent verdict de négligence criminelle prononcé contre deux anesthésistes britanniques devrait renforcer la responsabilité que tout médecin devrait porter envers ses actes. ${ }^{15}$ L'adoption d'un modèle de gestion de risque tel que préconisé par le Dr Eagle devrait diminuer la chance qu'on nombre suffisant de facteurs convergent vers une catastrophe. Il semble bien que le modus operandi du bloc opératoire puisse contribuer au risque anesthésique et qu'à ce titre, les anesthésistes ont le devoir d'en faire l'analyse critique s'ils veulent remplir leurs obligations quant à l'assurance de la qualité.

\section{References}

1 Rothman KJ. Causes. J Epidemiol 1976, 104, 587-92.

2 Duncan $P G$, Cohen MM. Pulse oximetry and capnography anaesthesia in practice: an epidemiological appraisal. Can J Anaesth 1991; 38: 619-25.

3 Cheney FW, Posner K, Caplan RA, Ward RJ. Standard of care and anaesthesia liability. JAMA 1989; 261: 1599-603.

4 Warden JC. Report of the New South Wales Special Committee investigating deaths under anaesthesia for the year ending June 30, 1988. Personal Communication to the Minister of Health in Australia.

5 Gaba DM, Maxwell M, Deande A. Anesthesia mishaps: breaking the chain of accident evolution. Anesthesiology 1987; 66: 670-6.

6 Eagle CJ, Davis J, Reason J. Application of a new model of accident analysis to an anaesthetic complication. Can J Anaesth 1991: this issue.

7 Friesen RM, Bjornson J, Hatton G. Anaesthetic machines and related patient monitors - a provincial hospital survey. Can J Anaesth 1989; 36: S60-1. 
8 Gellner D, Code WE, Duncan PG. Saskatchewan anaesthetic machines and related monitors: a hospital prevalence study. Can J Anaesth 1990; 37: S81.

9 Kumar $V$, Hintze MS, Jacob AM. A random survey of anesthetic machines and monitors in 45 hospitals. Anesth Analg 1988; 67: 644-9.

10 Allen GC. Dantrolene availability in Eastern Canadian hospitals. Can J Anaesth 1991; 38: A56.

11 Weinger $M B$, Englund $C E$. Ergonomic and human factors affecting anesthetic vigilance and monitoring performance in the operating room environment. Anesthesiology 1990; 73: 995-1021.

12 Duberman $S$. Quality assurance in the practice of anesthesia. Published by the American Society of Anesthesiology 1986; Park Ridge, Ill.

13 Wright $C J$. The fee-for-service system should be replaced. Can Med Assoc J 1991; 144: 900-3.

14 Brown FN, McIntyre RW. Is the tide turning? Can J Anaesth 1990: 37, 4-6.

15 Brahams D. Two anaesthetists convicted of manslaughter. Lancet 1990; 336: (ii): 430-1. 